\title{
8. Sınıf Öğrencilerinin Isı-sıcaklık Ünitesindeki Çizgi Grafiği ile İlgili Zorlukları Üzerine Disiplinlerarası Bir Çalışma
}

\author{
Betül TEKEREK ${ }^{1}$, Ümran Betül CEBESOY2,* \\ ${ }^{1}$ Kahramanmaraş Sütçüİmam Üniversitesi, Kahramanmaraş/TÜRKİYE; ${ }^{2}$ Uşak Üniversitesi, \\ Uşak/TÜRKIYYE
}

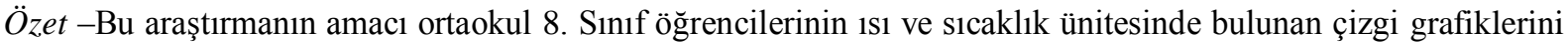
okuma, yorumlama ve çizme becerilerini incelemektir. Bu amaçla, 14 sorudan oluşan açık uçlu bir ölçek geliştirilmiş ve bu ölçek, 1sı ve sıcaklık ünitesinin işlenmesinin ardından öğrencilere uygulanmıştır. 2013-2014 akademik yarıyılında gerçekleştirilen araştırmaya, Ankara'da bulunan bir devlet ortaokulunda öğrenim görmekte olan 157 sekizinci sınıf öğrencisi katılmıştır. Veriler içerik analizi yöntemi ile çözümlenmiştir. Araştırmanın bulguları, öğrencilerin açık uçlu soruların yarısına doğru cevap verebildiklerini dolayısıyla 1sı-sıcaklık konusundaki çizgi grafiklerini okuma ve yorumlamada zorluk yaşadığını ortaya koymaktadır. Ayrıca, öğrencilerin sıcaklık farklarını bulmada zorluk yaşadıkları da saptanmıştır. Örneğin, araştırmaya katılan öğrencilerden \%15'i negatif sayılarda çıkarma işlemini doğru yapabilmiştir. Son olarak, öğrencilerin ısınma ve soğuma eğrilerini çizerken zorlandıkları tespit edilmiştir. Bu bağlamda, fen bilimleri ve matematik disiplinlerinin entegrasyonu ile ilgili çalışmaların arttırılmasına yönelik öneriler getirilmiştir.

Anahtar Kelimeler: çizgi grafiği, entegrasyon, 1s1-sıcaklık.

\section{Genişletilmiş Özet}

\section{Giriş}

Tarih boyunca birbirinden ayrı dersler olarak öğretilmesine rağmen, fen ve matematiğin özellikle son yıllarda entegre edilmesi düşüncesi, birçok araştırmaya konu olmakta ve birçok araştırmacı tarafından da desteklenmektedir (Basson, 2002; Batista ve Mathews, 2001; National Research Council [NRC], 2014). Bu iki disiplinin entegre edilmesi ile öğrencilerin bu derslerdeki başarılarının artacağı ve soyut kavramları bu sayede daha kolay

\footnotetext{
*İletişim-Sorumlu Yazar: Ümran Betül Cebesoy, Yrd. Doç. Dr., Uşak Üniversitesi, Eğitim Fakültesi, Matematik ve Fen Bilimleri Eğitimi Bölümü, Uşak, Türkiye

E-posta: betulcebesoy@yahoo.com
}

Not: Bu çalışmanın bir kısmı, International Society of Educational Research (ISER) World Conference 2014 Konferansında sözlü bildiri olarak sunulmuştur. 
somutlaştırabilecekleri vurgulanmaktadır (Hurley, 2001; McBride ve Silverman, 1991;ParkRogers, Volkmann, ve Abell, 2007). Ayrıca entegrasyonun öğrencilerin motivasyon, tutum ve grup çalışması yeteneklerini de olumlu şekilde etkilediği vurgulanmaktadır (Ross ve Hogaboam-Gray, 1998; Venville, Wallace, Rennie ve Malone, 2002). Bu çalışmaların yanında birçok araştırmacı tarafından da ortaya konulduğu üzere, öğrenciler matematikteki eksikliklerinden kaynaklı olarak fen bilimleri dersinde sorun yaşamaktadırlar. Özellikle birim çevirme, oran orantı, grafik ve grafik yorumlama, formül kullanımı ve dört temel işlem becerilerinin ediniminde yaşadıkları zorluklar bunlar arasında yer almaktadır (bknz. Bütüner ve Uzun, 2011; Demirci ve Uyanık, 2008; Kocaoğlu ve Yenilmez, 2010; Lamon, 2007; Tortop, 2011; Roth ve Bowen, 1999; Cebesoy \& Yeniterzi, 2014, 2016). Grafik okuma ve yorumlama, bu eksiklikler arasında en çok vurgulananlardan olmakla birlikte, her seviyeden öğrencinin hatta öğretmen adaylarının bile grafik yorumlama ve çizmede sorunlar yaşadığı ve bu sorunların özellikle fizik ve biyoloji derslerine olumsuz şekilde yansıdı̆̆ı yapılan çalışmalar sonucunda ortaya çıkmıştır (bknz. Aydın ve Delice, 2007; Demirci ve Uyanık, 2008; McDermonntt, Rosenquist ve van Zee, 1987). Ayrica 1s1 ve sicakl1k konusu ortaokul ders programlarında yer almasına karşın, lise ve üniversite öğrencilerinin bu konuda sıkıntılar yaşadığı da ilgili alan yazınında belirtilmektedir (Ateş ve Stevens, 2003; Aydoğan, Güneş ve Gülçiçek, 2003; Coştu, 2003). Bu bağlamda, 1sı sıcaklık konusunda yaşanan zorlukların temelinde grafik okuma, yorumlama ve çizme konusundaki sorunların olduğu sonucuna ulaşılabilir. Dolayısıyla, ortaokul seviyesindeki öğrencilerin 1s1-sıcaklık konusunda karşılaştığ1 grafikle ilgili zorlukların araştırılmasının önemli olduğu düşünülmektedir. $\mathrm{Bu}$ sebepten, bu çalışmada ortaokul 8. sınıf öğrencilerinin 1s1 ve sıcaklık ünitesinde bulunan çizgi grafiklerini okuma, yorumlama ve çizme becerilerinin incelenmesi amaçlanmaktadır. Elde edilecek bulgular ışığında, matematiksel bağıntılara değinme konusunda sınırlılık getirilen ortaokul fen bilimleri öğretim programının uygulayıcıları olan fen bilimleri öğretmenlerine grafikler konusunda öğrencilerin yaşayabileceği zorluklar ile ilgili farkındalık kazandırılması sağlanabilir. Ayrıca, fen ve matematik arasındaki disiplinlerarası ilişkiyi vurgulayan bu çalışmanın, özellikle fen bilimleri öğretmenleri için, fen ve matematik entegrasyonunun uygulanması konusunda yönlendirici ve motive edici olacağı öngörülmektedir.

\section{Yöntem}

Bu araştırma nitel araştırma yöntemi kullanılarak tasarlanmıştır. Araştırma 2013-2014 eğitim öğretim yılında Ankara'da bulunan bir devlet okulunda uygulanmıştır. Araştırmaya uygun örneklem yöntemiyle seçilmiş olan bu okulda öğrenim görmekte olan 157 sekizinci 
sınıf öğrencisi katılmıştır. Öğrencilere araştırmacılar tarafından hazırlanan 14 açık uçlu sorudan oluşan bir ölçek, fen bilimleri dersinde 1sı sıcaklık konusunun işlenmesinin ardından uygulanmıştır. Ölçekte yer alan ilk 12 soru, öğrencilerin grafik okuma ve yorumlamasına yönelik 1sı sıcaklık konusu ile ilgili sorulardan oluşmaktadır. Son iki soruda ise öğrencilerden, veriler kullanılarak ısınma ve soğuma eğrilerinden oluşan grafikler çizmeleri beklenmektedir. Verilerin çözümlenmesinde içerik analizi yöntemi kullanılmıştır. Analiz sonucunda elde edilen bulguların somutlaştırılması amacıyla, frekans, yüzdelik ve grafiklerden faydalanılmıştır.

\section{Bulgular}

Araştırmanın bulguları, öğrencilerin açı uçlu soruların yarısına doğru cevap verdiklerini dolayısıyla ısı-sıcaklık konusundaki çizgi grafiklerini okuma, yorumlamada ve bu grafikleri çizmede zorluklar yaşadığını ortaya koymaktadır. Öğrencilerin \%60’1 verilen grafiği doğru yorumlayarak verilen maddenin halini belirlemiş ve istenen sıcaklığı doğru şekilde yazabilmişlerdir. Ancak öğrencilerin yalnızca \%30’u hal değişimi esnasındaki verileri kullanarak grafiği doğru yorumlamış ve maddenin halini doğru bir şekilde yazabilmişlerdir. Örneğin, $100{ }^{\circ} \mathrm{C}$ 'deki suyun halini doğru yazan öğrenci sayısı oldukça azdır. Grafik çizme sorularında ise iki kere hal değişimi gerçekleşen 1sınma eğrisini öğrencilerin $\% 45^{\prime}$ lik bir bölümünün çizemediği ortaya çıkmıştır. \%31'i grafiği doğru şekilde çizebilmesine rağmen \%24'lük kısmı, sadece tek bir hal değişimini doğru şekilde grafiğe yansıtabilmiştir. Tek bir hal değişimi gerektiren soğuma eğrisi sorusunda ise öğrencilerin \%43'ü grafiği doğru şekilde oluşturabilmiştir. İki grafik çizimi sorusu birlikte değerlendirildiğinde tek bir hal değişimi gerektirmesine rağmen daha fazla öğrencinin soğuma eğrisini çizmede zorluk yaşadığ sonucuna ulaşılmıştır. Öğrencilerin sıcaklık farklarını bulmada da zorluk yaşadıkları görülmüştür. Örneğin araştırmaya katılan öğrencilerden yalnızca \%15'i sıcaklık farkını hesaplamada, negatif sayılarda çıkarma işlemini doğru olarak yapabilmişlerdir.

\section{Sonuç ve Tartışma}

Genel olarak incelendiğinde, bu çalışmanın bulguları, öğrencilerin 1s1-sıcaklık konusunda bilgi eksikliklerinin olduğunu göstermektedir. Alanyazında da tüm sınıf seviyelerinde öğrencilerin 1s1-sıcaklık konusunda kavramsal zorluklar yaşadığına değinilmektedir. Bu konudaki matematiksel zorluklar incelendiğinde ise öğrencilerin grafik okuma ve yorumlamada zorluk yaşadığı saptanmıştır (örneğin; Demirci ve Uyanık, 2009; Sülün ve Kozcu, 2005). Çalışmanın diğer bir bulgusu, öğrencilerin verilen maddenin hangi 
halde olduğunu, grafiğin y eksenindeki sicaklık verilerine bakarak daha kolay söyleyebildiklerini göstermektedir. Ancak aynı öğrencilerin x eksenindeki zaman verilerine bakarak maddenin hangi halde olduğunu ifade ederken zorlandığı görülmüştür. Diğer önemli bir sonuç ise, öğrencilerin soğuma eğrisi grafiğini çizerken (sudan buza geçiş) 1sınma eğrisi grafiklerine göre (buzdan suya ve sudan su buharına) daha çok zorlandıklarıdır. Bu sonuç, öğrencilerin grafikleri yorumlamada olduğu gibi, 1sı sıcaklıktaki grafikleri çizmede de zorluk yaşadığını göstermektedir. Isınma ve soğuma eğrilerinin çizimi, 1sı sıcaklıkla ilgili kavramsal bilgi, çizgi grafiğini okuma ve yorumlama becerilerini birlikte gerektirmektedir. Bu nedenle öğrencilerin 1sı sıcaklık konusundaki kavramsal bilgilerine ek olarak grafiklerde yorumlama becerilerinin de yeterli olmadığı sonucuna ulaşılabilir. Ayrıca, bu araştırmanın amacından bağımsız bir şekilde ortaya çıkan bir diğer bulgusu da öğrencilerin 1sı sıcaklık grafiklerini okuma ve yorumlama ile tamsayılarda çıkarma işlemini yapmada zorluk yaşaması olmuştur. Bu noktada, öğrencilerin tamsayılarda çıkarma işleminde yaşadıkları zorluğun çizgi grafiğgini okuma ve yorumlamalarını etkilediği söylenebilir.

\section{Öneriler}

$\mathrm{Bu}$ araştırma sonucunda elde edilen bulgulara dayanılarak araştırmacılara ve öğretmenlere yönelik aşağıdaki öneriler getirilmiştir:

- Isı sıcaklık konusundaki kavramların çizgi grafiğgi aracılığıyla görselleştirilerek sunulmasının, öğrencilerin öğrenmelerini kolaylaştıracağı düşünülmektedir.

- Tamsayılarda çıkarma işlemi ile ilgili olarak öğrencilerin ön bilgilerinin kontrol edilmesi ve var olan sıkıntıların giderilmesinin, 1S1-sıcaklık konusunun öğrenilmesinde yarar sağlayacağı düşünülmektedir.

- Matematik ve fen bilimleri arasındaki ilişkinin güçlendirilmesi ve öğrencilerin bu iki disiplini ilişkilendirebilmesi için fen bilimleri ve matematik öğretmenlerinin etkin bir şekilde ve sürekli olarak işbirliği yapmaları sağlanmalı ve teşvik edilmelidir.

- $\mathrm{Bu}$ çalışmada, öğrencilerin 1s1-sıcaklık konusundaki çizgi grafiklerini okuma, yorumlama ve çizmede yaşadıkları zorluklar incelenmiş olup, öğrencilerin diğer grafik türlerini okuma, yorumlama ve çizmede yaşadıkları zorluklar incelenebilir. Ayrıca, diğer fen konularında öğrencilerin yasadıkları zorluklar incelenebilir.

- Öğrencilerin fen konularında yaşadıkları grafik okuma, yorumlama ve çizme temelli zorlukların anlaşılmasının yansıra, bu zorlukların giderilmesine yönelik uygulama temelli araştırma çalışmaların yapılması da gerekmektedir. Çeşitli yöntemlerin ve tekniklerin öğrencilerin fen konularında yaşadıkları grafik okuma, yorumlama ve 
çizme temelli zorluklarını gidermede ne derece ekili olduğu deneysel çalışmalarla incelenebilir. 


\title{
An Interdisciplinary Study on $8^{\text {th }}$ Grade Middle Grade Students' Learning Difficulties of Line Graphs in Heat- Temperature Unit
}

\author{
Betül TEKEREK ${ }^{1}$, Ümran Betül CEBESOY ${ }^{2, *}$ \\ ${ }^{1}$ Kahramanmaras SutcuImam University, Kahramanmaras/TURKEY; ${ }^{2}$ Usak University, \\ Usak/TURKEY
}

Abstract - The purpose of this study is to investigate 8th grade middle school students' knowledge in reading, interpreting, and drawing line graphs in heat-temperature unit. 157 eight graders attending a public school in Ankara, Turkey, voluntarily participated in the study. A test composed of 14 open ended items was administrated to the students after the heat-temperature unit was taught at the beginning of the spring semester in 2013-2014 academic year. Content analysis method was used for data analysis. The findings showed that the students correctly answered slightly more than half of the questions in the test with a mean score of 51.3 out of 100 . Based on the findings, we inferred that students encountered difficulties in reading and interpreting graphs provided in the unit of heat and temperature. For instance, students had difficulties in calculation of temperature difference. With this respect, only a small percentage (15\%) correctly subtracted negative integers. Moreover, students had difficulties in drawing heating and cooling curves. Overall findings emphasized that we need further research on the integration of the disciplines of science and mathematics.

Key words: heat-temperature, integration, line graphs.

\section{Introduction}

There is an increasing consensus among scholars on the connection between different disciplines. Specifically, the connection between the disciplines of science and mathematics has been more prominent when compared to those between other disciplines. Historically, mathematics and science have been perceived individual subjects (Honey, Pearson \& Schweingruber, 2014). Even the two disciplines tended to be taught as isolated disciplines (Breiner, Harkness \& Johnson, 2012; Ríordáin, Johnson \& Walshe, 2016), integrating science

*Corresponding Author: Umran Betul Cebesoy, Ass. Prof. Dr., Usak University, Faculty of Education, Department of Mathematics and Science Education, Usak, Turkey

E-mail: betulcebesoy@yahoo.com

Note: Preliminary finding of this study was presented as oral presentation at the International Society of Educational Research World Conference (ISER), 2014, Nevsehir, Turkey 
and mathematics has been perceived as an important goal to be achieved (Basson, 2002; Batista \& Mathews, 2001). Moreover, achievement and learning in both disciplines depend on the successful integration of science and mathematics (Honey et al. 2014). The importance of this connection has been noticed and investigated by many researchers. Researchers stated that this may help students to be more successful in both disciplines, and that they can easily concrete their abstract concepts by using multiple representations (Hurley, 2001; McBride \& Silverman, 1991; Park-Rogers, Volkmann, \& Abell, 2007). For instance, McBride and Silverman (1991) reported that while science provided a meaningful context for abstract mathematics concepts, mathematics helped students to develop deeper understanding of science concepts concluding that the students learnt more effectively when the two were coherently connected. Moreover, this kind of connection was reported to increase students' interest and enhance their learning as well as increase student-teacher interaction (Venville, Wallece, Rennie, \& Malone, 2002). In another study conducted by Ross and Hogaboam-Gray (1998), it was reported that integrating different disciplines enhanced students' motivation and ability to work in group, and expanded their knowledge. Even these studies reported affective outcomes of integrating different disciplines, a meta-analysis investigating the effectiveness of integrating science and mathematics disciplines by reviewing 31 studies, Hurley (2001) did not reveal any affective outcomes. The researcher reported that students' achievement tended to increase while two disciplines were integrated, and that this was more evident in science compared to mathematics (Hurley, 2001).

Even though studies demonstrated that students' achievement in science tended to increase when science and mathematics were integrated (Hurley, 2001; Kurt \& Pehlivan, 2013; Selamet, 2014), it was also reported that students had many difficulties regarding mathematics in science classes (Basson, 2002; Howe, Nune, \& Brynth, 2010). Some of the difficulties students were faced with have been reported as unit analysis and conversion (Butuner \& Uzun, 2011; Kocaoglu \& Yenilmez, 2010), proportional concepts including direct and inverse proportion (Akatugba \& Wallece, 1999; Howe et al. 2010; Lamon, 2007), rate and ratio (Butuner \& Uzun, 2011; Dole \& Shield, 2008), graph-graphing and interpreting graphs (Cebesoy \& Yeniterzi, 2016, 2014; Capraro, Kulm, \& Capraro, 2005; Demirci \& Uyanık, 2008; McDermontt, Rosenquist, \& van Zee, 1987; Tortop, 2011; Roth \& Bowen, 1999), using mathematical formulas (Karakuyu, 2008; Sahin \& Yagbasan, 2012), and basic mathematical computations (Aydin \& Delice, 2007). Besides, other line of study findings 
indicated that teachers are also concerned about students' aforementioned difficulties (e.g., Kiray, Gok, Çaliskan, \& Kaptan, 2008; Offer \& Vasquez-Mireless, 1999; Zolnierczyk, 2016).

Graphs are visual tools that represent relationships among variables and used for communicating results (NRC, 1996; Ates \& Steven, 2003). Any kind of verbal and mathematical expressions can be visualized by using graphs (Celik \& Saglam-Arslan, 2012). In addition, drawing graphs help students to organize their findings as well as search patterns (NRC, 1996). Ates and Stevens (2003) stressed the importance of reading and interpreting graphs for the development of scientifically literate individuals. Thus, reading and interpreting graphs have been a topic of interest by many researchers (Cebesoy \& Yeniterzi, 2016, 2014; Ates \& Stevens, 2003; Capraro et al. 2005; Demirci \& Uyanık, 2008; McDermontt et al. 1987; Tortop, 2011; Roth \& Bowen, 1999). In a study conducted with university students, McDermontt et al. (1987) indicated that even students' had sufficient understanding regarding science, inability to interpreting graphs caused mathematical errors and caused difficulties in physics concepts. In another study conducted with pre-service mathematics teachers, Aydin and Delice (2007) reported that even students were moderately successful in measurement tasks, they had difficulties in interpreting and drawing graphs regarding physics experiments. Extending the research context to secondary school students, Demirci and Uyanik (2008) investigated the relationship between secondary school students' graphing ability and the kinematics graphs interpreting ability, and concluded that the students who were able to draw, understand and interpret graphs were more successful in understanding kinematics concepts. Likewise, Cebesoy, Yeniterzi and Mehmetlioglu (2016) examined middle school students' difficulties while interpreting graphs in a biology unit, specifically living organisms unit including photosynthesis, energy sources and food chains concepts, and reported that even though students were able to draw graphs, they displayed minimal understanding of ordering decimals, calculating basic addition and subtraction, and using direct proportion. The researchers interpreted these findings as limited understanding in such biology concepts might be linked to their limited understanding of basic mathematical concepts.

The implicit role of mathematics can be seen in all science concepts (NRC, 2006). While aforementioned studies (e.g., Cebesoy et al., 2016; Demirci \& Uyanik, 2008) focused on either physics or biology concepts, some researchers also investigated the role of reading and interpreting graphs in various chemistry concepts (e.g., Ates \& Steven, 2003; Aydogan, Gunes \& Gulcicek, 2003; Costu, 2007). For instance, investigating the relationship between students' performances and their conceptual and graphical understanding in gases, Costu 
(2007) reported students who interpreted graphics better tended to have conceptual understanding and thus performed better. The researcher underlined that the students had limited understanding in interpreting graphs. In another study, Aydogan et al. (2003) revealed that, both secondary school and undergraduate students had conceptual difficulties regarding heat and temperature concepts. Supporting this finding, Yeşilyurt (2006) stated that even learned in middle school, secondary school students still kept their conceptual difficulties in heat and temperature unit. It could be inferred that students' existing difficulties regarding heat and temperature concepts are originated from their learning of these concepts in middle school. In this sense, investigating middle school students' difficulties in reading and interpreting graphs in heat and temperature concept became a topic of question. As constructing and interpreting graphs have a significant role in science as well as in mathematics (Ozgun-Koca, 2001; Ates \& Stevens, 2003; and Tortop, 2011), we specifically focused on these concepts. Thus, line graphs were selected from mathematics, and heat and temperature from science. In this regard, the goal of this study was to examine 8th-grade middle school students' knowledge in reading, interpreting, and drawing line graphs. Specifically, we investigated the research question as follows:

What are the eighth grade middle school students' mathematical difficulties in reading, interpreting, and drawing line graphs in heat-temperature unit?

Even integration of different disciplines was referred in national science education program (Ministry of National Education [MoNE], 2006), there is no direction for teachers to how to connect different disciplines in the curriculum guidelines. With the recent curriculum reform in middle school science curriculum which has been disseminated from the beginning of 2013, the integration of mathematics with science has become more ambiguous. Even there are restrictions for teachers to use limited mathematics formulas in science classes that are offered as a compulsory part of middle education in state schools in Turkey, there is no clear direction for integration of mathematics into science classes (MoNE, 2013). With this study, we hope to stress the undeniable role of mathematics in science classes. In addition, taking into consideration the critically important role of teachers who are the implementers of integration in their classes, we hope to encourage them for further integration possibilities. 


\section{Method}

Based in the aim of our investigation, namely examination of eight grade students' mathematical difficulties in reading, interpreting, and drawing line graphs in heat-temperature unit, we employed interpretive basic qualitative study. Different classification schemes are used in qualitative research design. These schemes are case study, phenomenology, ethnography, narrative research (Merriam, 2009; Suter, 2011). Basic qualitative research is not classified within these schemes (Merriam, 2009). By using basic qualitative research, we attempted to uncover the participants' experiences as Merriam (2009) indicated.

\section{Participants}

The participants of this study were 157 eight grade middle school students attending a public school in Ankara, Turkey. They were selected by using convenient sampling method due to time and travel constraints from a public middle school in Kecioren, a district of Ankara. Convenient sampling is one of the sampling techniques which is used in qualitative research (Luborsky \& Rubenstein, 1995; Marshall, 1996). Even this sampling strategy may yield unrepresented selection of participants in the study, it is one of the strategies that can be adopted during participant selection (Marshall, 1996). We tried to reach diverse groups (different students in different classes) and many students in order to prevent any underrepresentation of student groups. Thus, we had a sample including 157 students. At the time of the study, there were 4 groups of $8^{\text {th }}$ graders in the school. They were mostly coming from families with low socioeconomic status. The data were collected in the second semester of 2013-2014 academic year. The following section outlines data collection tool and data analysis.

\section{Data Collection}

A test consisting of open-ended items was developed by the researchers in line with the research questions as in Merriam (2009)'s definition of researcher-generated documents to gather much detailed and rich information from students' answers. The test items were prepared considering the objectives of the subjects of heat-temperature, and line graph which are identified in the national science curriculum, and that of mathematics, respectively . The students were supposed to learn the heating and cooling curves in heat-temperature unit considering the fact that they already learnt how line graph is drawn and interpreted in their previous schooling. The data were collected by the science teacher of each class. One of the researcher was available in the class during data collection procedure to clarify points -if any. 


\section{Data Collection Tool}

A test with 14 open-ended items was developed by the researchers who are specialized in science and mathematics education. In the development process of test, related literature about students' difficulties in reading and interpreting graphs were taken into consideration. In addition, the objectives of current national science and mathematics curricula were examined. Out of 14 open-ended items, students were asked to answer 12 questions by reading and interpreting line graphs regarding changing of states. Thereby, it was aimed to determine the difficulties caused by poor mathematical knowledge of the students. They were also expected to understand the given statements regarding changing of states and then, to draw line graphs in the rest of two questions. Specifically, the focus of these two questions was to understand to what extent the concepts of changing of states in heat and temperature unit are represented in their mind, and to what extent they put this piece of knowledge into practice by drawing line graphs which exist in their mathematical knowledge (See Appendix for sample questions). Content validity of the test was ensured by taking expert opinions. A teacher of mathematics and two teachers of science were requested to review it in terms of understandability, clarity, and appropriateness to the curriculum objectives. Additionally, each researcher coded the data independently, and compared each regarding consistency. Tables and graphs were also used while interpreting the questions in the test in order to ensure quasistatistics for validity stated by Maxwell (1998).

40 minutes ( 1 class hour) were assigned to students for completing the test. Data were gathered after the heat and temperature unit was completed. Students' scores were calculated over 100 points. While they got 7 points for each in 12 questions which required reading and interpreting of the graphs, they got 16 points in total for the rest two questions related to drawing a line graph. The correct answer of one of the two questions related to drawing line graph including changing state twice was calculated as 10 points. The correct answer of the other item which investigated students' knowledge in changing state was calculated as 6 points.

\section{Data Analysis}

Content analysis method was used for analyzing the data collected from $8^{\text {th }}$ graders attending a state pre-secondary school in Turkey. Content analysis is an interpretation technique that is used for analyzing human behavior in an indirect way throughout written documents such as textbook, essays, student homework, student exam papers (Fraenkel \& 
Wallen, 2006; Y1ldırım \& Simsek, 2008). For fulfilling the purpose of present research, exam sheets of the students were examined to understand their knowledge in reading, interpreting, and drawing line graphs.

Quantizing of qualitative data is a common interpretation technique known as counting method for determining and comparing the frequencies of codes and categorizes (Miles \& Huberman, 1994). The data were collected and quantized. In order to examine students' understanding and errors related to graphical knowledge in heat and temperature unit, frequencies and percentages were formed.

\section{Findings}

The findings were presented under two headings: In the first part, findings regarding students' total test scores were presented. In the second part, students' correct, incorrect, and partially correct answers to each question were presented by using graphs.

\section{Investigation of students' total scores in heat and temperature unit}

The findings revealed that students got a mean score of 51.3 out of 100 indicating that they correctly answered slightly more than half of the questions in the test. This implies that they had difficulties in interpreting and drawing graphs regarding heat and temperature unit. To be more specific, nearly $60 \%$ of them correctly responded to the items on the states of matter and the temperature of the states by interpreting line graphs. However, less than half of the students (nearly $30 \%$ ) could correctly answer the questions on changing states of matter; namely, failed to they determine/ inform the state of matter at $100^{\circ} \mathrm{C}$ or $0^{\circ} \mathrm{C}$ ). Moreover, students had difficulty in interpreting and calculating the temperature difference of given matters. Additionally, only $15 \%$ of them correctly calculated the temperature difference by subtracting negative integers. Another significant finding of the study might be that the students had difficulties in drawing line graphs. While approximately half of them (43\%) correctly drew the cooling curve of water, only $30 \%$ of them correctly drew the heating curve of water, which indicated that they were having difficulties in stating/ deciding on temperature increase and decrease in a line graph.

\section{Students' mathematical difficulties heat and temperature unit}

In this part, we examined students' mathematical difficulties with respect to each question in the test. Students encountered difficulties in determining the state of given matter; 
condensation and melting points of the matters; the temperature difference in a certain time interval as well as the direction of these changes and drawing line graphs.

Students' difficulties in determining the state of given matter

In Q1 and Q7, students were asked to determine the state of given matter through interpreting temperature in the graphs. While more than half of the students $(62 \%)$ were able to answer correctly Q1 which was related to interpreting a heating curve, 38\% of them gave incorrect responses. On the other hand, less than half of the students could correctly respond to Q7 which required them to interpret a cooling curve (41\%). As shown in Figure1 below, their correct answers decreased in interpreting cooling curve when compared to their correct responses related to heating curve. It could be concluded that they had more difficulty in interpreting the state of given matter in the cooling curve than heating curve.

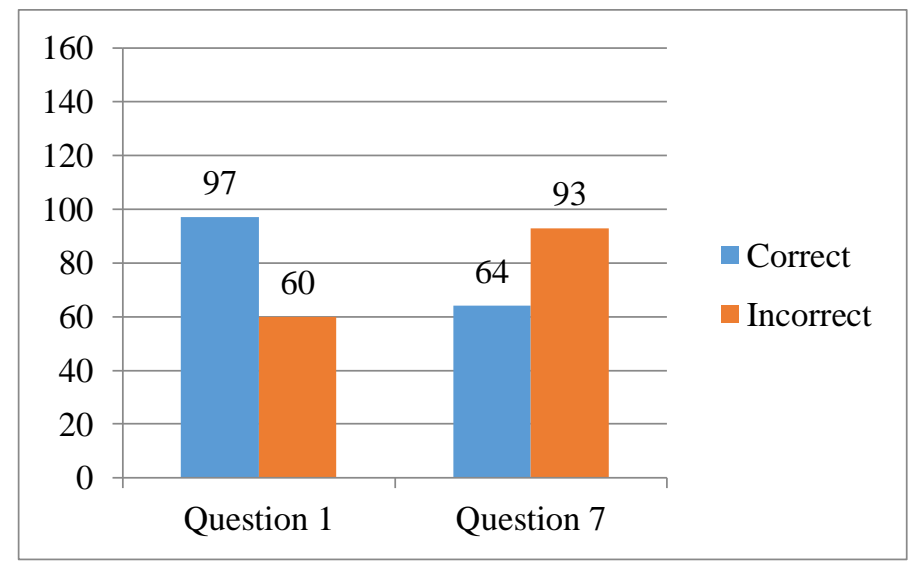

Figure 1 Students' Correct and Incorrect Responses to Q1 and Q7

In Q3 and Q6, the students were asked to determine the state of a given matter through interpreting exact time points in the graphs. Much less than half of the students were able to correctly answer Q3 which was required them to interpret a heating curve (34\%). On the other hand, less than half of the students could correctly respond to Q6 which was related to interpreting a cooling curve (31\%). Considering Figure 2 below, it could be claimed that there is a balanced distribution among students who provided correct and incorrect responses to the items on cooling and heating curves. 


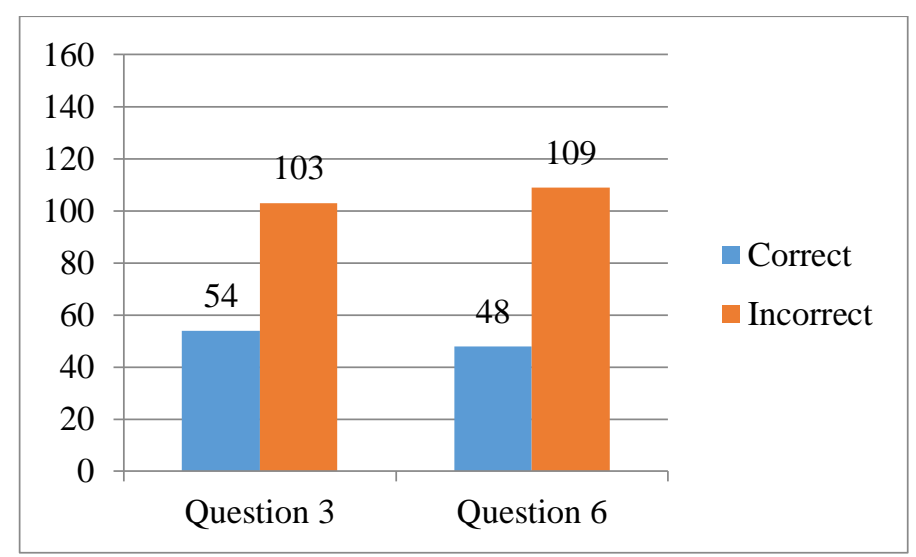

Figure 2 Students' Correct and Incorrect Responses to Q 3 and Q6

When students' correct answers compared as in Figure 1 and Figure 2, it could be seen that students tended to determine the state of matter by interpreting the temperature points (which were found in $\mathrm{Y}$ axis as independent variables) easier when compared to interpret time points (which were found in $\mathrm{X}$ axis as dependent variable) in the graphs. This can be attributed to the teacher's tendency to ask more questions which can be answered by interpreting the $\mathrm{Y}$ axis when compared to interpreting time points in graphs.

Students' difficulties in determining the boiling, condensation and melting points of the matters

Q2 and Q11 were posed to the students in similar ways to determine the boiling points of the given matters. Q11 was differentiated from Q2 as it includes two phase changes. Interestingly, more than half of the students $(60 \%)$ correctly identified the boiling points of the matters in both questions regardless the number of phase change. In a similar way, students were able to determine the condensation (Q5) and melting points (Q10) $(63 \%$ and $65 \%$, respectively). To conclude, students seem to have a tendency to answer the question related to the boiling, condensation and melting points of the matters correctly by reading and interpreting the graphs correctly (see Figure 3).

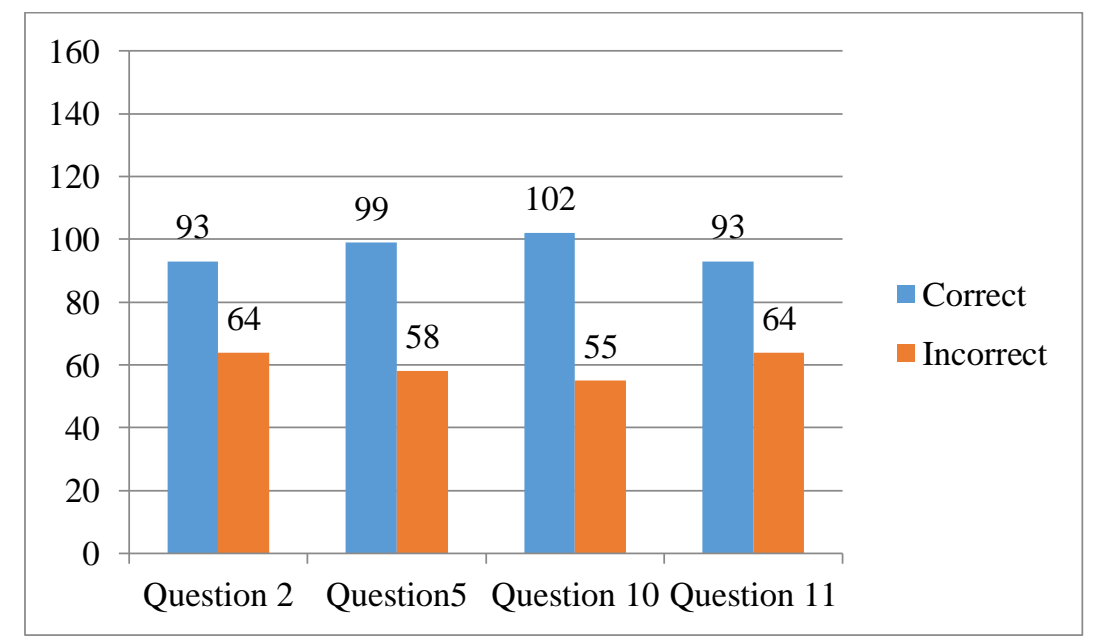


Figure 3 Students' Correct and Incorrect Responses to Q2, Q5, Q10 and Q11

In Q9, the students were asked to decide how many times the matter changed phase by interpreting the given graph. The majority of the students were able to determine the number of phase change (78\%), $20 \%$ of them could not correctly respond to the item.

Students' difficulties in determining the temperature difference in a certain time interval and the direction of these changes

In Q4, Q8, and Q12, students were asked to calculate the temperature difference in a certain time interval as well as to clarify the direction of these changes (whether it is increasing or decreasing) by inferring from given graphs. To be more specific, while $39 \%$ of the students correctly answered Q4, 40\% of them provided partially correct answer to the item in concern. When the partial answers were examined, it was seen that $38 \%$ of them were able to determine the direction of the change (as increasing in $4^{\text {th }}$ question), and that only a few students could subtract two positive integers (e.g., 70-25). On the contrary to Q4, more than half of the students gave partially correct answer to Q8 (53\%). Similar to the previous question, students tended to determine the direction of the change (as decreasing in $8^{\text {th }}$ question). Only a few students could subtract a positive integer from a negative integer (e.g., $(-50)-10)(1 \%)$. That is, the total percentage of the correct answers was decreased to $16 \%$. While there was one phase change in previous questions, there were two phase changes in Q12. The percentages of the students' correct and incorrect answers were same (34\%) (see Figure 4). Like in the previous questions, $27 \%$ of the students correctly determined the direction as increasing in $12^{\text {th }}$ question. However, $5 \%$ of them could successfully subtract two negative integers (e.g., (-20) - (-40)). To conclude, it could be claimed that students had a tendency to correctly determine the direction of the temperature change, and that most of them had difficulty in subtracting integers. Specifically, it was easier to subtract to positive integers when compared to subtracting negative integers for students. On the contrary, items involved the students to subtract positive integer from a negative integer revealed the most difficult for the students. 


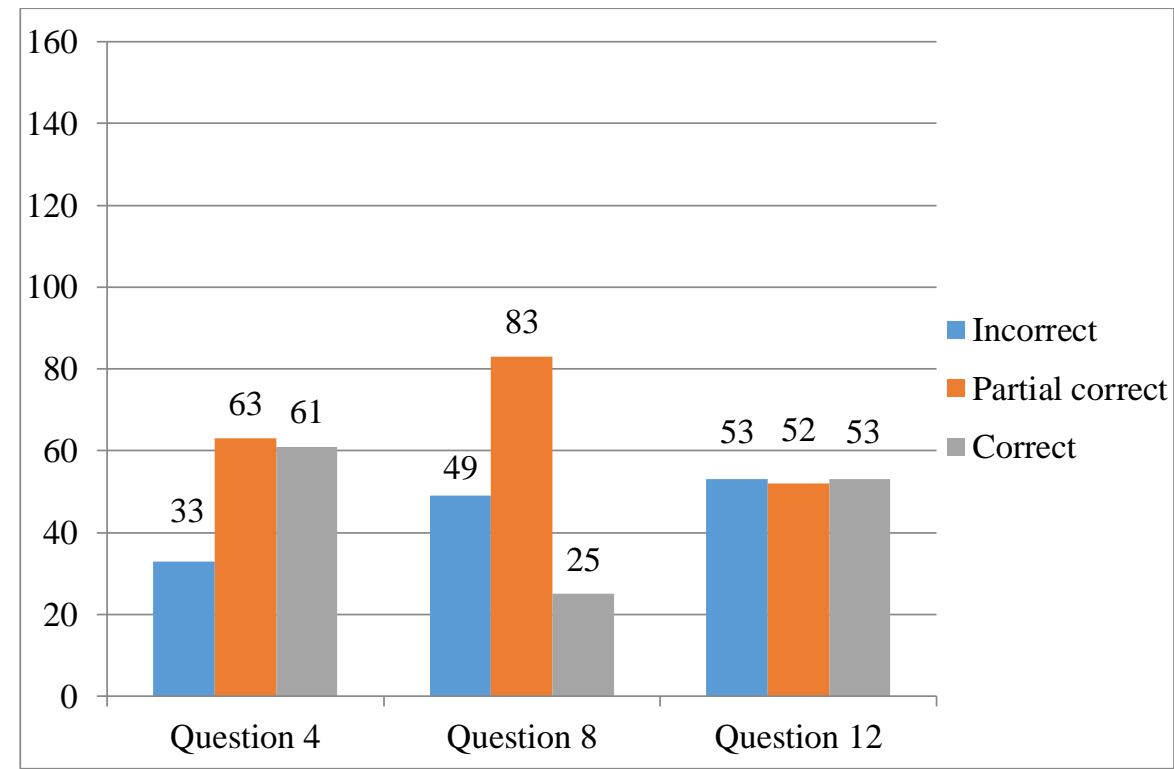

Figure 4 Students' Correct and Incorrect Responses to Q4, Q8 and Q12

\section{Students' difficulties in drawing line graphs}

In Q13, the students were asked to draw a heating curve which included two phase changes (from ice to water and from water to water vapor). Approximately, half of the students failed to draw a heating curve on an empty heat-temperature graph (45\%). While $31 \%$ were able to correctly draw two phase changes, approximately a quarter of them could only draw one phase change (24\%). This finding indicated that even students were able to determine the number of phase changes on a given graph, they had difficulty in drawing the exact number of phase changes.

Nearly half of the students $(43 \%)$ were able to correctly draw a cooling curve which consisted of one phase change in Q14 (from water to ice). When the numbers of incorrect answers provided to Q13 and Q14 were compared, it was revealed that the students had more difficulty in drawing a cooling curve (45\% and 57\%, respectively).

\section{Discussions}

In the present study, we investigated mathematical difficulties encountered by $8^{\text {th }}$ grade middle school students in reading, interpreting, and drawing line graphs in heattemperature unit. For this purpose, we used a test consisting of 14 open-ended items related to the concepts in heat and temperature unit. Students read and interpreted the line graphs in Q1 to Q12 and they drew a heating curve in Q13, and a cooling curve in Q14. The findings showed that students had difficulties in reading and interpreting line graphs while answering the questions in the heat-temperature unit. This particular finding is in line with previous 
studies with respect to students' difficulties in heat and temperature unit (e.g., Aydin \& Godek Altuk, 2013; Bulus, Kirikkaya \& Gullu, 2008; Yesilyurt, 2006). Namely, Aydin and Godek Altuk (2013) investigated university students' conceptions related to state of matters, and reported that they could mention state of matter without specifying temperature. Similarly, Bulus, Kirikkaya and Gullu (2008) reported that 5th grade students had difficulties in learning heat and temperature as well as evaporation and boiling concepts. Even though these studies did not specifically investigate students' mathematical difficulties in heattemperature unit, it is evident that regardless of the degree of education (middle school, secondary school or university level), students have conceptual difficulties in heattemperature unit.

Some other studies investigated students' difficulties while reading and interpreting graphs in different science topics (e.g, Demirci \& Uyanik, 2009; McDermott et al. 1987; Sulun \& Kozcu, 2005). For instance, McDermott and colleagues (1987) explored university students' difficulties related to drawing and interpreting the graphs in physics concepts, and reported that understanding and interpreting graphs is essential in solving real world physics problems. In a similar vein, Sulun and Kozcu (2005) studied students' conceptual difficulties with respect to interpreting graphs in population size and population dynamics topic (a biology concept). They reported that they held misconceptions in interpreting graphs in this topic, and that they were unable to interpret the $\mathrm{X}$-axis and $\mathrm{Y}$-axis in the graphs. Overall, the authors interpreted that both their insufficient knowledge in population dynamics and inability to interpret the graphs in the given questions resulted in low level of understanding of population dynamics. We also came up with similar conclusions for heat-temperature unit in this study. The students participating our study successfully determined the state of matter by interpreting the temperature points (which were found in $\mathrm{Y}$-axis as independent variables) much easier when compared to time points (which were found in $\mathrm{X}$-axis as dependent variable) in the graphs. It might be attributed to the science teacher's tendency to ask more questions which could be answered by interpreting $\mathrm{Y}$-axis when compared to interpreting time points (X-axis) in graphs.

Another important finding was that while nearly half of the students were unable to draw a heating curve (from ice to water and from water to water vapor), more than half were unable to draw a cooling curve (from water to ice) on an empty heat-temperature graph. In fact, this was an expected finding since they were only able to answer half of the questions in 
the test implying that they had difficulties in interpreting and drawing graphs regarding heat and temperature unit. In other words, the students who had limited understanding in drawing and interpreting line graphs were also could not draw line graphs in heat-temperature unit. In line with this finding, investigating the relationship between middle school students' drawing line graphs and interpreting line graphs, Yayla and Ozsevgec (2015) previously reported a positive relationship between students' drawing and interpreting line graphs. Drawing heating and cooling curves require both conceptual knowledge in heat and temperature unit as well as interpretation skills and understanding in line graphs. That is, it could be concluded that they did not have sufficient knowledge in heat and temperature unit and lacked interpretation skills in line graphs. Actually, they could easily learn the concepts in heat- temperature unit by using line graphs as they help them to visualize the context. In a similar manner, Ozgun-Koca (2001) stressed the importance of graphs in order to give complex information influentially not only in mathematics but also in science or social studies.

As an additional and interesting result, we also found that the students had difficulty in subtraction of a negative integer from a negative integer (for instance, (-50)-10). In line with this finding, examining students' difficulties in computations related to integers, Avcu and Durmaz (2011) reported that $6^{\text {th }}$ and $7^{\text {th }}$ graders tended to subtract a small number from a large number. They used the example of $(-15-3=-12)$ for supporting their findings. It couold be stated that $8^{\text {th }}$ grade students had still difficulties in the subtraction of integers although they have learnt addition and subtraction in integers in $6^{\text {th }}$ grade. In this sense, Varol and Kubanc (2012) conducted a literature review about students' difficulties in four computation skills in mathematics. They emphasized that their errors in the subtraction of integers could have stemmed from overgeneralization of rules in subtraction in natural numbers. Moreover, investigating the effect of multiple intelligence theory based instruction on $7^{\text {th }}$ grade students' mathematics achievement in integers unit, Koroglu and Yesildere (2004) reported that students could not differentiate addition and subtraction in integers. Although investigating the students' difficulty in subtraction of integers was not the aim of the current study, it could be concluded that students' understandings and interpretations of line graphs were also affected by the problem in concern.

\section{Suggestions and Implications for Further Research}

In the light of the findings of the study, we might conclude that the participant students showed limited understanding in reading, interpreting and drawing line graphs in 
heat-temperature unit. The inability of reading, interpreting and drawing line graphs might have resulted in limited understanding in the concepts related to heat and temperature unit. Thus, several suggestions could be proposed as follows:

First, before teaching concepts in heat-temperature unit, students' graph reading, interpreting, and constructing abilities should be checked and additional time should be allowed for reading and interpreting graphs in science course if needed. Additionally, checking students' prerequisite knowledge in subtraction of integers is also needed since it affected students' achievement in interpreting line graphs. Collaboration between science and mathematics teachers should be ensured to empower the relationship between the two disciplines, and to help students to connect them. Moreover, it is considered that permanency could be easily provided for students' learning once the subjects of heat-temperature and graphs are taught in science and mathematics classes coherently and in an integrated manner,. Computer-assisted education programs can also be helpful/ useful for making learning of these subjects easier for the students. In line with this suggestion, Yeşilyurt (2006) conducted a study regarding views of secondary school students in the first and second year about heat and temperature concepts. He suggested that misconceptions in heat and temperature concepts could be handled by using computer-assisted programs which allow drawing graphs regarding phase changes and calculate heat changes. Ozgun- Koca (2001) also emphasized the importance of computer assisted graph instruction suggesting some electronic resources to utilize in order to enhance students' graphical skills.

Further research might be conducted on the connection between graph types and other science topics and difficulties students encounter in learning the subjects of science might be examined in detail. Additionally, teachers' awareness about the difficulties faced by the students in reading, interpreting and drawing graph types could be examined. If the teachers are aware of these problems, the collaboration between science and mathematics could be achieved. Ríordáin et al. (2015) stated that teachers have positive view of integration of science and mathematics. This positive view is a key for implementation of integrated lessons (Cebesoy \& Yeniterzi, 2016). Therefore, further studies might scrutinize integration of science and mathematics in real classroom settings.

Students' motivation and academic achievement in mathematics and science will increase if teachers are aware of the importance of integration of different disciplines. This could be achieved by pre-service teacher education programs. It is considered that an integrated teacher education program that consider the importance of integration of science 
and mathematics is needed. Likewise, Berlin and White (2012) reported pre-service teachers showed positive attitudes and perceptions about the integration of different disciplines. Thus, the researchers also believe adapting this kind of integrated pre-service teacher education programs will be helpful in raising prospective teachers. Moreover, this kind of approach will enhance the collaboration and teamwork between teachers as indicated in Frykholm and Glasson (2005). 


\section{Appendix-1 Examples from the test}

\section{Questions from 1 to 4:}

\section{1.- 4. Soruları bu grafiğe göre cevaplayınız.}

Başlangıçta sıvı halde bulunan bir X maddesinin sıcaklık-zaman grafiği şekildeki gibidir.

1. $50{ }^{\circ} \mathrm{C}$ 'de bu madde hangi haldedir?

2. Bu maddenin kaynama sıcaklığı kaç derecedir?

3. 15. dakikada bu madde hangi halde bulunmaktadır?

4. 25. dakikada maddenin başlangıçtaki haline göre sıcaklık değişimi kaç ${ }^{\circ} \mathrm{C}$ 'dir?

\section{Sicaklık $\left({ }^{0} \mathrm{C}\right)$}

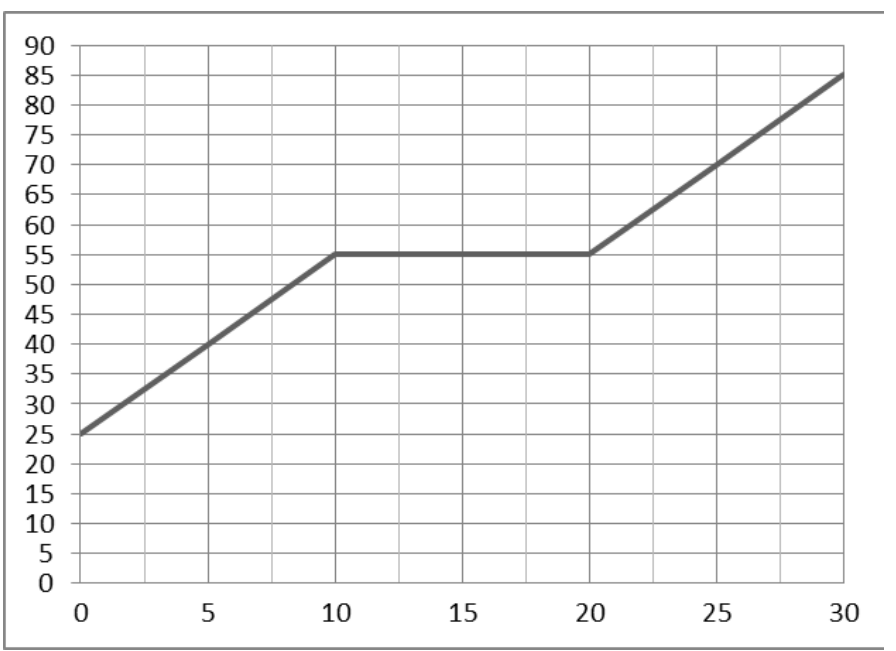

\section{Question 14.}

$45^{\circ} \mathrm{C}$ 'de bulunan suyun $-15^{\circ} \mathrm{C}^{\prime}$ ye gelinceye kadar gerçekleşen sıcaklık değişim grafiğgini çiziniz.

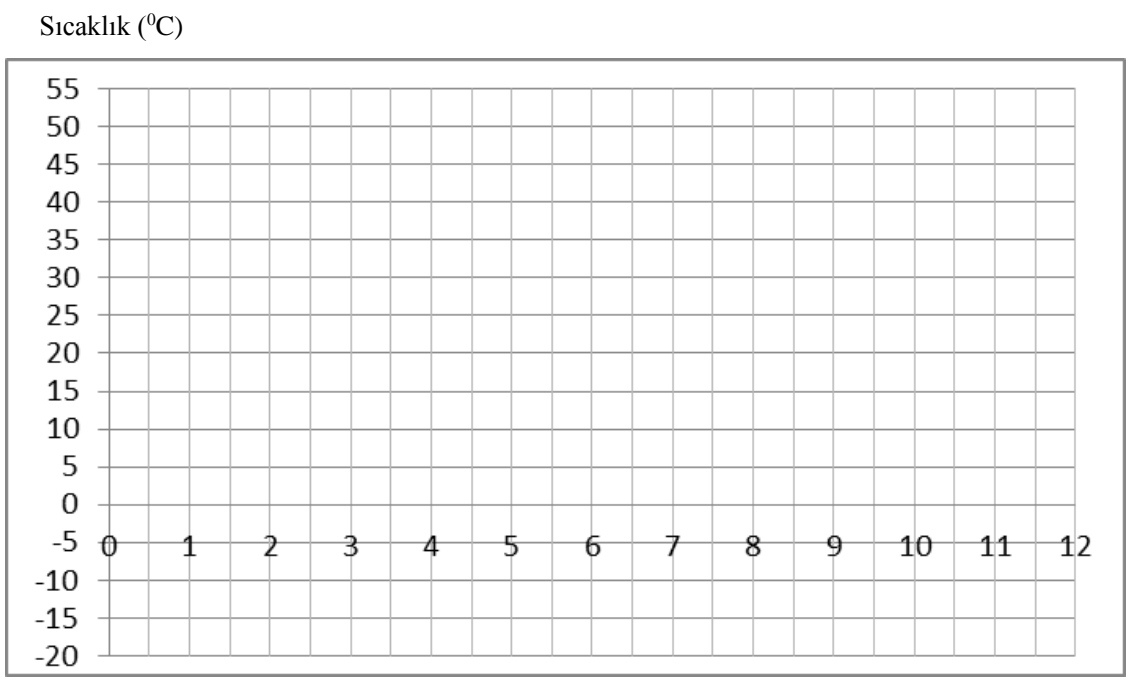




\section{References}

Akatugba, A. H., \& Wallace, J. (1999). Sociocultural influences on physics students' use of proportional reasoning in a non-western country. Journal of Research in Science Teaching, 36(3), 305-320.

Ates, S., \& Stevens, J. T. (2003). Teaching line graphs to tenth grade students having different cognitive developmental levels by using two different instructional modules. Research in Science \& Technological Education, 21(1), 55-66.

Avcu, T., \& Durmaz, B. (2011- April). Tam sayllarla ilgili işlemlerde ilköğretim düzeyinde yapılan hatalar ve karşılaşılan zorluklar. Paper presented at 2nd International Conference on New Trends in Education and their Implications, Antalya-Turkey.

Aydin, A., \& Altuk, Y. G. (2013). Turkish science student teachers' conceptions on the states of matter. International Education Studies, 6(5), 104-115.

Aydin, E., \& Delice, A. (2007). Experiences of mathematics student teachers in a series of science experiment. Proceedings of the 6th WSEAS International Conference on Education and Educational Technology, 58-63. Retrieved from http://files.eric.ed.gov/fulltext/ED502605.pdf

Aydogan, S., Gunes, B., \& Gulcicek, Ç. (2003). Isı ve sıcaklık konusunda kavram yanılgıları. Gazi Eğitim Fakültesi Dergisi, 23(2),111-124.

Basista, B.,\& Mathews, S. (2002). Integrated science and mathematics professional development programs. School Science and Mathematics, 102(7),359-370.

Basson, I. (2002). Physics and mathematics as interrelated fields of thought development using acceleration as an example. International Journal of Mathematical Education in Science and Technology, 33(5), 679-690.

Beauford, J.E. (2009). The great divide: How mathematics is perceived by students in math and science classrooms. Science Scope, 33(3), 44-48.

Breiner, J. M., Harkness, S. S., Johnson, C. C., \& Koehler, C. M. (2012). What is STEM? A discussion about conceptions of STEM in education and partnerships. School Science and Mathematics, 112(1), 3-11. Doi: 10.1111/j.1949-8594.2011.00109.x

Butuner, S. Ö. \& Uzun, S. (2010). Fen öğretiminde karşılaşılan matematik temelli sıkıntılar: Fen ve teknoloji öğretmenlerinin tecrübelerinden yansımalar. Kuramsal Eğitimbilim,4(2), 262-272. 
Capraro, M. M., Kulm, G., \& Capraro, R. M. (2005). Middle grades: Misconceptions in statistical thinking. School Science and Mathematics, 105(4), 165-174.

Capraro, M. M., Kulm,G., \& Capraro, R. M. (2005). Middle grades: Misconceptions in statistical thinking. School Science and Mathematics, 105(4), 165-174.

Cebesoy, U. B., \& Yeniterzi, B. (2014). Investigation of science and technology exam questions in terms of mathematical knowledge. Procedia - Social and Behavioral Science,116, 2711-2716. doi:10.1016/j.sbspro.2014.01.641

Cebesoy, U. B. \& Yeniterzi, B. (2016). Seventh grade students' mathematical difficulties in force and motion unit. Turkish Journal of Education, 5(1), 18-32. doi: $10.19128 /$ turje. $51242 \mathrm{v}$

Cebesoy, U. B., Yeniterzi, B. \& Mehmetlioglu, D. (2016). An example of integrating mathematics to science: Graphs and living organisms. J. Lavonen, K. Juuti, J. Lampiselkä, A. Uitto \& K. Hahl (eds.). E-Book Proceedings of the ESERA 2015 Conference: Science Education Research: Engaging learners for a sustainable future. Part 17 (co eds. B. Bungum \& P. Nilsson) (pp. 2813-2822), Helsinki, Finland: European Science Education Research Association.

Costu, B. (2007). Comparison of students' performance on algorithmic, conceptual and graphical chemistry gas problems. Journal of Science Education and Technology, 16(5), 379-386.

Demirci, N., \& Uyanik, F., (2009). Onuncu sınıf öğrencilerinin grafik anlama ve yorumlamaları ile kinematik başarıları arasındaki ilişki. Necatibey Faculty of Education Electronic Journal of Science and Mathematics Education, 3(2), 22-51.

Dole, S., \& Shield, M. (2008). The capacity of two Australian eighth-grade textbooks for promoting proportional reasoning, Research in Mathematics Education, 10(1), 19-35, doi: $10.1080 / 14794800801915863$

Fraenkel, J.R., \& Wallen, N.E. (2006). How to design and evaluate research in education. New York: McGraw-Hill.

Frykholm, J., \& Glasson, G. (2005). Connecting science and mathematics instruction: Pedagogical context knowledge for teachers. School Science and Mathematics, 105(3), 127-141.

Honey, M., Pearson, G., \& Schweingruber, H. (Eds.). (2014). STEM integration in K-12 education: Status, prospects, and an agenda for research. National Academies Press. 
Howe, C., Nune, T., \& Brynth, P. (2010). Rational number and proportional reasoning: Using intensive quantities to promote achievement in mathematics and science. International Journal of Science and Mathematics Education, 9, 391- 417.

Hurley, M. M. (2001). Reviewing integrated science and mathematics: The search for evidence and definitions from new perspectives. School Science and Mathematics, 101(5), 259-268.

Kıray, S. A., Gok, B., Çaliskan, I., \& Kaptan, F. (2008). Perceptions of science and mathematics teachers about the relations between what courses for qualified science mathematics education in elementary schools. In O.Demirel \& A.M.Sunbul (Eds.). Further Education in the Balkan Countries 2, (pp. 889-897). Thessaloniki: Balkan Society for Pedagogy and Education

Kırıkkaya, E. B., \& Güllü, D. (2008). İlköğretim Beşinci Sınıf Öğrencilerinin Isı-Sıcaklık ve Buharlaşma-Kaynama Konularındaki Kavram Yanılgıları. İlköğretim Online, 7(1). 1527

Kocaoğlu, T., \& Yenilmez, K. (2010). Beşinci sınıf öğrencilerinin kesir problemlerinde yaptıkları hatalar ve kavram yanılgıları. Dicle Üniversitesi Ziya Gökalp Eğitim Fakültesi Dergisi, 14, 71-85.

Korogu, H, \& Yesildere, S., (2004). İlköğretim yedinci sınıf matematik dersi tamsayılar ünitesinde çoklu zeka teorisi tabanlı öğretimin öğrenci başarısına etkisi. Gazi Eğitim Fakültesi Dergisi, 24(2), 25-41.

Kurt, K. \& Pehlivan, M. (2013). Integrated programs for science and mathematics: Review of related literature. International Journal of Education in Mathematics, Science and Technology, 1(2), 116-121.

Lamon, S. J. (2007). Rational numbers and proportional reasoning: Towards a theoretical framework for research. In F. K. Lester (Ed.), Second handbook of research on mathematics teaching and learning (pp. 629-667). Charlotte: Information Age Publishing.

Luborsky, M. R., \& Rubinstein, R. L. (1995). Sampling in qualitative research: Rationale, issues, and methods. Research on aging, 17(1), 89-113.

Marshall, M. N. (1996). Sampling for qualitative research. Family practice, 13(6), 522-526. 
McBride, J. W., \& Silverman, F. L. (1991). Integrating elementary/middle school science and mathematics. School Science and Mathematics, 91(7), 285-292. Doi: 10.1111/j.19498594.1991.tb12102.x

McDermott, L.C., Rosenquist, M.L.\& van Zee, E.H. (1987). Student difficulties in connecting graphs and physics: Examples from kinematics. American Journal of Physics, 55(6), 503-513.

Merriam, S. B. (2009). Qualitative research: A guide to design and implementation (2nd ed.). San Francisco (CA): John Wiley \& Sons.

Miles, M. B., \& Huberman, M. (1994). Qualitative Data Analysis: A Sourcebook of New Methods. 2. Beverly Hills, CA: Sage Publications.

Ministry of National Education [MONE]. (2006). Ilkogretim fen ve teknoloji dersi (6, 7 ve 8. siniflar) ogretim programi. Ankara. Retrieved from http://ttkb.meb.gov.tr

Ministry of National Education.[MONE]. (2013). Fen bilimleri dersi ogretim programi (3, 4, 5, 6, 7, ve 8. sinuflar). Ankara. Retrieved from http://ttkb.meb.gov.tr

Offer, J.,\& Vasquez-Mireles, S. (2009). Mix it up: Teacher's beliefs on mixing mathematics and science. School Science and Mathematics, 109(3), 146-152.

Ozgun-Koca, S. A. (2001). The graphing skills of students in mathematics and science education. Retrieved from http://www.gpoaccess.gov/eric/200211/ed464804.pdf.

Park-Rogers, M. A., Volkmann, M.J., \& Abell, S. K. (2007). Science and mathematics: A natural connection. Science and Children, 45(2), 60-61.

Park-Rogers, M. A., Volkmann, M.J., \& Abell, S. K. (2007). Science and mathematics: A natural connection. Science and Children, 45(2), 60-61.

Ríordáin, M. N., Johnston, J., \& Walshe, G. (2016). Making mathematics and science integration happen: key aspects of practice. International Journal of Mathematical Education in Science and Technology, 47(2), 233-255.

Ross, J. A., \& Hogaboam-Gray, A. (1998). Integrating mathematics, science, and technology: effects on students. International Journal of Science Education, 20(9), 1119-1135.

Roth, W. M., \& Bowen, G. M. (1999). Complexities of graphical representations during ecology lectures: An analysis rooted in semiotics and hermeneutic phenomenology. Learning and Instruction, 9(3), 235-255.

Necatibey Eğitim Fakültesi Elektronik Fen ve Matematik Eğitimi Dergisi

Necatibey Faculty of Education, Electronic Journal of Science and Mathematics Education 
Selamet, C. S. (2014). Beşinci sinif öğrencilerinin tablo ve grafik okuma ve yorumlama başari düzeylerinin incelenmesi (Unpublished master thesis). Afyon Kocatepe University, Turkey.

Sulun, Y., \& Kozcu, N. (2005). İlköğretim 8. Sınıf öğrencilerinin lise giriş sınavlarındaki çevre ve populasyon konusuyla ilgili grafik sorularını algılama ve yorumlamalarındaki yanılgıları. Erzincan Üniversitesi Ë̆itim Fakültesi Dergisi, 7(1), 25-33.

Suter, W. N. (2011). Introduction to educational research: A critical thinking approach. SAGE publications.

Tortop, T. (2011). 7th-Grade students' typical errors and possible misconceptions in graphs concept before and after the regular mathematics instruction (Unpublished master thesis). Middle East Technical University, Turkey.

Varol, F., \& Kubanc, Y. (2012). Öğrencilerin dört işlemde yaşadıkları yaygın aritmetik güçlükler. International Periodical For The Languages, Literature and History of Turkish or Turkic, 7(1), 2067-2074.

Venville, G. J., Wallace, J., Rennie, L. J., \& Malone, J. A. (2002). Curriculum integration: Eroding the high ground of science as a school subject? Studies in Science Education, 37, 43-83.

Yayla, G. \& Ozsevgec, T. (2015). Ortaokul öğrencilerinin grafik becerilerinin incelenmesi: Çizgi grafikleri oluşturma ve yorumlama. Kastamonu Eğitim Dergisi, 23(3), 1381-1400.

Yesilyurt, M. (2006). High school students' views about heat and temperature concepts, International Journal of Environmental and Science Education, 1(1), 1-24.

Yıldırım, A. \& Şimşek, H. (2008). Sosyal bilimlerde nitel araştırma yöntemleri. Ankara: Seckin Publishing.

Zolnierczyk, J. (2016). Perspectives of teachers regarding the integration of mathematics and science at the secondary school level (Unpublished master thesis). Queen's University, Canada. 